University of Nebraska - Lincoln

DigitalCommons@University of Nebraska - Lincoln

Summer 1992

\title{
The Character of Surface Archaeological Deposits and Its Influence on Survey Accuracy
}

\author{
LuAnn Wandsnider \\ University of Nebraska - Lincoln, Iwandsnider1@unl.edu \\ Eileen Camilli \\ University of New Mexico, Albuquerque, New Mexico
}

Follow this and additional works at: https://digitalcommons.unl.edu/anthropologyfacpub

Part of the Anthropology Commons

Wandsnider, LuAnn and Camilli, Eileen, "The Character of Surface Archaeological Deposits and Its Influence on Survey Accuracy" (1992). Anthropology Faculty Publications. 18.

https://digitalcommons.unl.edu/anthropologyfacpub/18

This Article is brought to you for free and open access by the Anthropology, Department of at DigitalCommons@University of Nebraska - Lincoln. It has been accepted for inclusion in Anthropology Faculty Publications by an authorized administrator of DigitalCommons@University of Nebraska - Lincoln. 


\title{
The Character of Surface Archaeological Deposits and Its Influence on Survey Accuracy
}

\author{
LuAnn Wandsnider \\ University of Nebraska-Lincoln \\ Lincoln, Nebraska
}

\section{Eileen L. Camilli}

University of New Mexico

Albuquerque, New Mexico

Survey is one of the primary methods of data collection in archaeology today. Survey data often constitute the sole conserved record of the prehistoric use of an area and are used as the foundation for culture historical, demographic, and economic reconstructions. Given the fundamental nature of survey data in relation to other archaeological pursuits, identification of biases inherent in this type of data are important and have been the subject of a number of stimulating studies. Analyses reported here focus on the accuracy of results produced through intensive survey. Using data from several siteless surveys in the American West, the effects of artifact obtrusiveness, especially size, and artifact density on the survey accuracy are investigated. Implications for interpreting a biased archaeological document are addressed.

\section{Introduction}

Archaeological survey, the discovery and documentation of prehistoric and historical cultural remains on modern surfaces, is responsible for a growing portion of the information we have about the prehistoric use of various areas (Ammerman 1981; Dunnell and Dancey 1983; Lewarch and O'Brien 1981). In the United States, this expansion has been prompted in part by legal mandates requiring regional inventories of historical and prehistoric resources (Judge 1981; Raab 1979). Simultaneously, data obtained through archaeological survey have come to be viewed as of equal or even greater utility to those obtained through excavation since (1) they are logistically and economically easier to obtain (Cherry 1983; Dunnell and Dancey 1983); (2) they afford a regional perspective on prehistoric activities (Cherry 1983, 1984; Dunnell and Dancey 1983); and (3) archaeological deposits are not necessarily destroyed by the documentation process and results, theoretically, can be replicated (Cherry 1983).

Problems with surface archaeological deposits, and hence with the use of archaeological survey data, however, are not insignificant (Lewarch and O'Brien 1981), although most have been dismissed. For example, the contention that surface remains have less integrity than buried remains (e.g., Hope-Simpson 1983, 1984) appears trivial when recognizing that buried deposits were at one time on the surface and subject to the same disturbances impacting modern surfaces (Cherry 1984; Dunnell and Dancey 1983).

Other recognized problems concern the quality of the survey results and quality control in archaeological survey (Cowgill 1986, 1989; Powell, Leat, and Thomas in press). As archaeological survey contributes increasingly to the overall knowledge of prehistoric occupancy of an area, so too has concern increased about what survey results actually represent. This concern is evident in the pioneering work of Plog, Plog, and Wait (1978) and Schiffer, Sullivan, and Klinger (1978). These studies examined the factors influencing the accuracy and consistency of survey results. Related studies have demonstrated the effects of different sampling procedures (e.g., Judge 1981; contributions to Mueller 1975; Plog 1976) and survey intensity (e.g., Cowgill 1990; Plog, Plog, and Wait 1978; Schiffer and Wells 1982) on survey results. O'Brien and colleagues (1982) have reported on the effects of both differential visibility owing to vegetation and potential fluctuation in crew member interest on the results of their Oaxaca survey. Foley $(1981 \mathrm{a}, 1981 \mathrm{~b}, 1981 \mathrm{c})$, in his survey of the Am- 
boseli (Kenya), and Gallant (1986), in his survey of two Greek islands, addressed bias in their survey results introduced by varying amounts of groundcover.

This study focuses on the characteristics of surface archaeological deposits and how the completeness and consistency of survey results are influenced by these characteristics. The data employed in this analysis were obtained during three intensive, siteless surveys and utilize both experimental "seeding" data and assemblage data. We first explore the effect of two characteristics of archaeological deposits, artifact obtrusiveness and density, on survey results. We then consider the implications of these effects for traditional site survey and more recent siteless survey efforts. By way of introduction, clarification of several terms is offered.

\section{Measuring the Archaeological Record}

The archaeological document with which archaeologists return from the field is a product of several factors, only one of which is the archaeological deposit itself. Here, we distinguish between the surface archaeological record, i.e., the empirical reality of the surface archaeological deposits (similar to Cowgill's [1970] potential finds population), and the surface archaeological document, similar to Cowgill's physical finds population. Following Cherry (1983, 1984), Dunnell and Dancey (1983), and Lewarch and O'Brien (1981), the surface archaeological record is assumed to be as suitable an object of study as is the total archaeological record, with both surface and subsurface components. Further, both the archaeological document and record are considered contemporary phenomena that differentially reflect past systemic behavior.

The agreement between the archaeological document and the archaeological record varies as a function of factors such as artifact obtrusiveness, density, and clusteredness, and others mentioned above. This relationship between record and document is described by terms such as accuracy, precision, reliability, and validity. Rarely are survey procedures evaluated with respect to these qualities; instead, archaeological survey is almost always assumed to produce accurate, precise, reliable, and valid results (but see Plog 1986; Powell, Leat, and Thomas in press).

Such assessments, however, have been made by archaeologists (e.g., Beck and Jones 1989; Bowers, Bonnichsen, and Hoch 1983; Nance 1981, 1988; Read 1986) in discussing both direct measurement of the archaeological record and indirect measurement of past behavior. Here, we use Nance's (1988: 248-249) distinction to discriminate between making measurements on the content and configuration of an archaeological record and making measurements on aspects of the past, e.g., occupation span or curation behavior. The first involves direct measurements made on objects, while the second involves indirect measurement, since the past cannot be directly experienced. In this paper, we are most concerned with the accuracy of direct measurements made on the archaeological record, since indirect measures of curation or occupation span, for example, are contingent on the quality of these observations. Much of the following discussion can be construed in terms of the discovery of archaeological sites. We will concentrate, however, on the discovery of artifacts since it is artifacts and features that are actually observed by the archaeologist, while sites are entities that must be analytically defined and may be so defined in a variety of ways.

Validity has to do with the quality of indirect measurement, i.e., the extent to which they actually measure the target phenomena. For example, psychologists (cf. Carmines and Zeller 1979; Zeller and Carmines 1980) measuring personality traits and cultural anthropologists (Bernard 1988: 48-61) interested in monitoring quality of life, are highly concerned with the validity of the questionnaires they use to measure these complex qualities. Likewise, Nance (1988: 281-282) discusses the validity of faunal element frequencies as a measure of qualities of prehistoric diet. Since we are interested in the representativeness of observations made on the archaeological record itself, rather than the past, the question of measurement validity is not raised in the discussion that follows.

Other terms in measurement parlance, however, are quite pertinent. Precision, reliability, and accuracy are attributes both of measuring instruments and direct measurements made with those instruments. In this case, they refer to survey procedures and results. Precision and reliability are often used interchangeably. Here, we follow Bernard (1988: 49) in usage of these terms. Precision refers to the resolving power of the measurement instrument. Traditional moderate-intensity site survey, for example, faithfully measures the numbers and locations of archaeological manifestations with standing architecture. It is less faithful with respect to documenting small artifact scatters and reproduces even less faithfully the locations of individual artifacts. Thus, the level of precision of moderate-intensity survey is at the resolution of archaeological sites with standing architecture (Cowgill 1990).

Reliability refers to the agreement between, or among, two or more measurements made on the same phenomenon. A reliable measuring instrument yields measurements with a small amount of error that is randomly, not systematically, distributed. If multiple executions of a site survey 
procedure in the exact same area yielded varying frequencies of different kinds of artifacts, then that procedure would be considered unreliable. Conversely, if statistically unvarying frequencies of the archaeological phenomenon had been obtained, then the procedure and results would both be considered reliable.

Accuracy relates to the deviation between actual and measured. An accurate measuring device produces measurements with a small deviation, i.e., with little bias or systematic error, given a stipulated level of precision. Accurate archaeological survey generates a document that is a faithful representation of the archaeological record with respect to the target characteristics. In recent years, the domain of archaeological phenomena over which archaeologists attempt to obtain an accurate and reliable picture has expanded; the level of survey precision demanded by archaeological questions has become finer. Not only are architectural features sought, but also remains that are less obtrusive. It is for this reason that archaeologists have increased the intensity and evenness of survey.

What are the specific characteristics of the archaeological record that survey procedures should accurately and reliably portray? The answer depends on the desired level of precision, which is determined by the questions being asked of the record. For all levels of precision, however, frequency of an archaeological phenomenon is one obvious attribute. Another is the state of the discovered phenomenon specified to a desired level of detail. For example, correctly identifying the artifact states of "ceramic," vs. "chipped stone," vs. "fire-altered rock," vs. "ground stone," vs. "other" may be appropriate in some instances. In others, correctly specifying "flake" from "core" from "angular debris" from "worked tool" may be important. The vast literature on sampling and sampling within the context of archaeological survey is concerned entirely with the faithful and simultaneous depiction of these two characteristics, frequencies and state of a given phenomenon.

Another aspect of the archaeological record that has become increasingly important to archaeologists is its spatial structure, i.e., the spatial relationships among like and different archaeological phenomena. Sampling is designed to generate frequency estimates of a given class of phenomenon. It is difficult, however, to sample for structure without knowing beforehand the nature of that structure. For this reason, some archaeologists (contributors to Fish and Kowalewski 1990) have called for full-coverage survey, i.e., survey of large expanses of land. Insofar as such survey can guarantee the accurate recording of all instances of phenomena in state $\mathrm{X}$ for a given area, then a faithful picture of the spatial relationship between those phenom- ena can also be assumed. With such a picture of the archaeological landscape, questions that demand structural data can be addressed.

The focus of this paper is on evaluating the accuracy of a more precise (relative to site survey) documentation procedure given variable densities and degrees of artifact obtrusiveness. Previous work in this area (Camilli, Wandsnider, and Ebert 1988; Larralde 1990; Wandsnider 1989; Wandsnider and Ebert 1984; Wandsnider and Larralde 1986) suggests that an accurate portrait of the archaeological record may be tied directly to attributes of artifact abundance, clustering, and obtrusiveness. The present effort is therefore directed towards better specifying the parameters of the relationship between document accuracy and these record characteristics.

\section{Character of Surface Archaeological Deposits}

Attributes of archaeological deposits that influence how that deposit is documented include, among other things, the obtrusiveness of artifacts, their clustering, and their density. Obtrusiveness refers to the probability of discovery of an archaeological phenomenon given the survey technique (Schiffer, Sullivan, and Klinger 1978: 6). The obtrusiveness of high-density artifact scatters with a diameter of $30 \mathrm{~m}$ is high if the survey transect spacing is $15 \mathrm{~m}$ or less. Obtrusiveness of the same archaeological phenomenon would be reduced given survey procedures with a transect spacing wider than $15 \mathrm{~m}$ (see Cowgill 1990: 252-256). Probability of discovery is also affected by surface visibility, which is conditioned by extent and nature of vegetation and sedimentation. Thus, architectural remains on a scoured land surface are more obtrusive than those in a pine forest. In this study, survey methods were held constant (see below) and groundcover was sparse, with the result that obtrusiveness is almost solely referable to characteristics of the artifacts themselves and their distribution. Attributes of artifact obtrusiveness considered here include artifact color, size, and shape.

Schiffer and colleagues (1978; see also Read 1986) considered the effects of two other deposit characteristics, frequency (or abundance or density) and clusteredness, on discovery. If the frequency of an archaeological phenomenon (i.e., artifact or site) is high or these phenomena are not highly clustered, then the total frequency in state $\mathrm{X}$ may be estimated from an accurate and reliable survey of a relatively small area. The spatial relationships among different and similar kinds of phenomena, however, cannot be estimated from the sample. As abundance falls or archaeological remains become more clustered, sample survey becomes a less reliable way of documenting the 
character of an archaeological surface distribution, even with respect to frequency, since survey within the sample units may or may not encounter archaeological remains. That is, the variance about the artifact frequency estimate increases dramatically as the target population decreases in size or becomes more aggregated. In this study, the effects of density and clusteredness on survey results are considered.

\section{Survey Projects and Study Areas}

The data used in this analysis were collected from three pedestrian surveys (FIG. 1) that employed similar field methods and shared personnel. One survey was part of the Seedskadee Cultural Resource Assessment Project (Drager and Ireland 1986; Ebert, Larralde, and Wandsnider 1987; Wandsnider and Larralde 1986) and was conducted by Chambers Consultants and Planners of $\mathrm{Al}$ buquerque for the National Park Service and Bureau of Reclamation during the summer of 1983. It was part of an evaluation of the cultural resources that might be affected by a land exchange and took place on Bureau of Reclamation lands that encompass the Seedskadee National Wildlife Refuge and Fontenelle Reservoir in sw Wyoming. The second survey (Camilli, Wandsnider, and Ebert 1988) was performed in the winter and spring of 1985 by the Bureau of Land Management on some of its lands in New Mexico near El Paso, Texas, that were to pass out of federal ownership as part of the Navajo-Hopi Land Exchange. The third survey was executed in the summer of 1987 as part of an instrumentation feasibility study by Ebert and Associates of Albuquerque for the National Science Foundation Small-Business Innovation Research Program (Camilli, Wandsnider, and Ebert 1987). It was performed on Bureau of Land Management land near the archaeological site of Tonque Pueblo in central New Mexico.

The Seedskadee project area lies in the Green River Basin of Wyoming between the Wind River Mountains to the NE, the Wasatch Mountains to the west, and the Uinta Mountains to the south. In this area, wind and water erosion and deposition have differentially sculpted cobble-capped terraces. The resulting landscape is one that is moderately diverse in terms of both the different suites of geomorphological processes at work on the surface and the local landforms (see Larralde 1990). Dune fields, alluvial flats, playa deposits, and cobble terraces all may be found within kilometers of each other and relief can be as great as $30 \mathrm{~m}$ over a distance of $500 \mathrm{~m}$. Sparse sage, greasewood, and grass dominate the vegetative communities throughout the area; pebbles and gravels also occur on some surfaces. Twenty-five units, each $500 \mathrm{~m}$ on a side, were surveyed and 20,000 pieces of chipped stone and fire-altered rock were discovered, coded, and mapped.

The Navajo-Hopi project area lies in the Mesilla Bolson of south-central New Mexico just north of the Mexican

Figure 1. Locations of study areas.

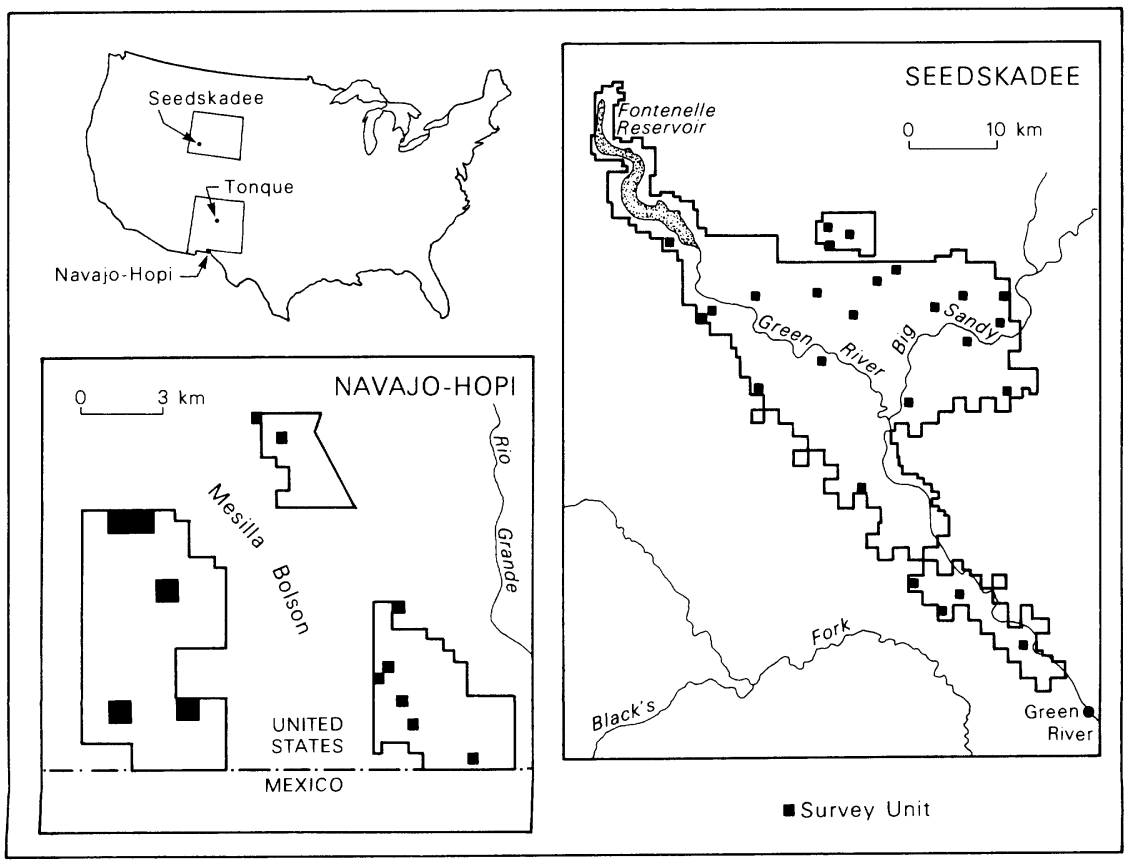


border. The Rio Grande, to the east, is the nearest major drainage, and the Portillo Mountains rise to the west of the project area. The bolson is the relic of an ancient, internally drained basin. Today, it is mantled with coppice dunes anchored by mesquite in some parts and yucca in others. Localized occurrences of sand sheets that appear to be presently inactive are also found; naturally occurring gravels, the majority of them less than $2 \mathrm{~cm}$ in diameter, were found in dune blowouts. Compared with the Seedskadee project area, the Navajo-Hopi area has a very low diversity in type of landform. Over a distance of $400 \mathrm{~m}$, elevation may vary at most $5 \mathrm{~m}$ and usually much less. Bureau of Land Management personnel surveyed 28 units, each $400 \mathrm{~m}$ on a side. In these, 30,400 pieces of chipped stone, ceramics, and fire-altered rock were discovered, coded, and mapped.

The Tonque project survey area, measuring $400 \mathrm{~m} \times$ $400 \mathrm{~m}$, lies on the north-trending slope of a dissected pediment associated with the northern Sandia Mountains about $30 \mathrm{~km}$ NE of Albuquerque, New Mexico. Arroyo Tonque, which flows into the nearby Rio Grande, bounds the project area to the north and Arroyo Una de Gato, a tributary of Arroyo Tonque, lies to the south. Juniper parkland covers approximately the central third of the area; to the south is a gently-sloping expanse of snakeweed and to the north is a broken terrace covered with low shrubs. Pebbles of various colors are a common feature of some portions of the unit. Ebert and Associates personnel surveyed this single unit and recorded approximately $\mathbf{2 3 0 0}$ sherds, pieces of chipped stone, and feature-related cobbles.

In each area, siteless survey procedures were followed. Siteless methods include off-site, non-site, and other survey procedures. In such procedures, the artifact is the unit of discovery, but typically the unit of collection and analysis is the survey unit. These analytic units may vary in size from $66.6 \mathrm{sq} \mathrm{m}$ (Seaman, Doleman, and Chapman 1988a), to $250 \mathrm{sq} \mathrm{m}$ (Foley 1981c), to 1 ha (IrwinWilliams et al. 1988), to 13 ha (Button 1987), to 25 ha (Bettinger 1976, 1977; Thomas 1971, 1973, 1975), or, if defined by the extent of an agricultural field (O'Brien et al. 1982; Bintliff and Snodgrass 1985, 1988), may be of any size. Such data are used to discuss variation in the densities of specific kinds of artifacts across large expanses of land. Similar to the procedures employed by Dancey (1973) and Davis (1975), the survey procedures utilized during the projects described here not only used the artifact as the unit of discovery, but mapped artifacts to the nearest centimeter or meter. In this manner, the higherresolution spatial information of artifact distributions was conserved. Thus, this suite of field techniques has been termed distributional to distinguish it from other siteless field methods (Ebert, Larralde, and Wandsnider 1987).

Distributional methods involved the intensive $(5 \mathrm{~m}$ transect interval) and controlled (transect guides are established prior to survey) survey of small parcels of land (500 $\mathrm{m}$ on a side for the Seedskadee survey and $400 \mathrm{~m}$ on a side for the other two). The locations of all artifacts were marked with orange pinflags as they were found by a five-person "discovery" crew. The artifact locations were later visited by a separate crew that encoded up to 15 attributes for each artifact using a predetermined, computer-compatible coding scheme. In the earlier Seedskadee and Navajo-Hopi surveys, codes were manually transcribed onto FORTRAN forms and later entered into computer files. In the later Tonque survey, artifact attribute codes were entered directly into hand-held field computers; these files were later transferred to the laboratory computer for analysis. While visiting the artifacts to code them, other artifacts were inevitably noticed and these were flagged in red to distinguish them from those found during the systematic survey. All discovered artifacts were mapped by a third two-person crew. An Electronic Distance Measuring (EDM) theodolite was used to map, to the nearest centimeter, about half of the Seedskadee and three-quarters of the Navajo-Hopi artifacts. In high artifact density areas, a grid system with movable tapes was used to record the provenience of artifacts to the nearest meter. All provenience information was initially handtranscribed and then entered into computer files. In the Tonque survey, no provenience grid system was employed. Furthermore, in contrast to the other two surveys, a data receiver attached to the EDM logged the point-provenienced data, which were later transferred to the laboratory computer.

This study makes use of two kinds of data that were collected as part of these surveys. The first comes from the "seeding" of survey units with painted hardware prior to survey. With these experimental data, the characteristics of the archaeological document can be directly compared with the known characteristics of the seeded archaeological record. The second kind of data comprises the population of prehistoric artifacts that were recorded during controlled survey, flagged in orange, and those found during the second unsystematic encoding pass through the survey unit, flagged in red. Ratios of orange-flagged artifacts to the total sample of discovered artifacts are used in the second set of analyses.

\section{Seeding Experiments}

The seeding experiments consisted of introducing a known quantity of a contemporary material into a unit 
prior to its survey. Palynologists use a similar technique to "spike" their samples with an easily recognizable exotic pollen or sphere that behaves like pollen so that recovery and sedimentation rates can be estimated (e.g., Davis 1967, 1976).

\section{Seedskadee Seeding Experiment}

This first experiment considered the accuracy of the distributional survey procedure with respect to artifact obtrusiveness, as measured by geometry and color, and clusteredness. Seedskadee Unit 24 was seeded, prior to survey, with 203 contemporary artifacts, washers (D. $1.5 \mathrm{~cm}$; surface area $1.77 \mathrm{sq} \mathrm{cm})$ and nails $(5 \mathrm{~cm}$ in length; surface area $1.5 \mathrm{sq} \mathrm{cm}$ ) spray-painted black and buff. ${ }^{1}$ Two different sorts of distributions were mimicked through seeding: "isolated occurrences" and "sites" (artifact clusters). Isolated artifacts were laid out according to no particular plan, but cannot be said to have been randomly distributed. Varying shapes and densities of artifact clusters were introduced onto the landscape. The seeded artifacts were mapped as they were introduced into the survey tract. These objects were then discovered and recorded in the same manner as all prehistoric artifacts (i.e., flagged in orange during the first survey pass and flagged in red if found by encoding or mapping crew members).

The frequencies of discovered and undiscovered seeded artifacts are summarized in Table 1 . In general, more of the slightly smaller but more "unnaturally" shaped washers (71\%) were recovered as opposed to larger but less unnaturally shaped nails $(61 \%)$. More black $(70 \%)$ artifacts, which contrasted most with surface sediments, were recovered than buff $(62 \%)$ artifacts. In terms of the interaction of seed shape and tone, a greater proportion of the black, unnaturally-shaped washers $(73 \%)$ were found as were a lower proportion of the buff, stick-like nails (53\%); intermediate proportions of buff washers $(68 \%)$ and black nails $(64 \%)$ were recovered.

Dramatically more clustered $(82 \%)$ than isolated (16\%) artifacts were recovered. Further, as cluster density increased, so did the proportion of total seeded artifacts recovered (FIG. 2). That clusters consisted of all black, all buff, all nail, all washer, or mixed assemblages, may contribute to the lack of uniformity in the observed positive relationship between artifact density and discovery. That is, only $10 \%$ of the artifacts in the "Nail" cluster were found and this may be owing to the low density of the

1. The figures presented here vary slightly from those presented in Wandsnider and Ebert (1984) and in Wandsnider and Larralde (1986), owing to editing of these data; the trends observed there remain unchanged. cluster as well as to the diminished obtrusiveness of the nails themselves. More data points in each of these different categories would be required to adequately document the interaction between size, color, and density.

The observed disparity in the recovery rates for clustered vs. isolated artifacts is to be expected if, as often assumed, the discovery process is a two-step process. The first step is to find any and all artifacts within the $1-2 \mathrm{~m}$ that immediately surround the feet of the surveyor. The second step, expanding inspection outside of the immediate 1$2 \mathrm{~m}$ transect, is implemented only if the first step successfully yields artifacts.

If surveyors are held responsible for the discovery of all artifacts within the 1-2 m transects, spaced $5 \mathrm{~m}$ apart, then between $20 \%$ and $40 \%$ of the ground surface is inspected. Assuming a random distribution of the isolated artifacts on this inspected surface, $20-40 \%$ of these isolated artifacts should have been discovered. Furthermore, all artifacts should be represented in the discovery population in proportion to the frequency with which they occur on the archaeological surface. Neither of these expectations was met, which suggests that bias, owing to artifact obtrusiveness, exists. Sixteen percent of the isolated artifacts were recovered, which is not far below the $20 \%$ expectation. Thirty percent of the most obtrusive isolates-black washers-were found. None of the buff nails, the least obtrusive isolates, were found, however, and lower-than-expected percentages of isolates with intermediate obtrusiveness were found.

Artifact obtrusiveness appears to contribute greatly to the differential discovery of artifacts in the low density case, where obtrusive black washers were recovered at about the expected rate but all other artifacts, which are relatively less obtrusive, were recovered in very low proportions. In the high density case, artifact obtrusiveness is also a factor, but its effects appear less extreme. In the case of the least obtrusive artifact class, buff nails, $73 \%$ of the clustered artifacts were found; about $85 \%$ of the clustered artifacts in the other more obtrusive classes were recovered.

One last observation is appropriate. Of all the isolated seeded artifacts that had been discovered (i.e., both orange- and red-flagged artifacts), the discovery crew found $62.5 \%$ and the encoding crew found $37.5 \%$. In contrast, a majority of the clustered seeded artifacts discovered were found by the discovery crew (85\%) as compared with the encoding crew $(15 \%)$. This finding has important implications for the discovery of clustered and unclustered archaeological remains by traditional site survey and is discussed below. 


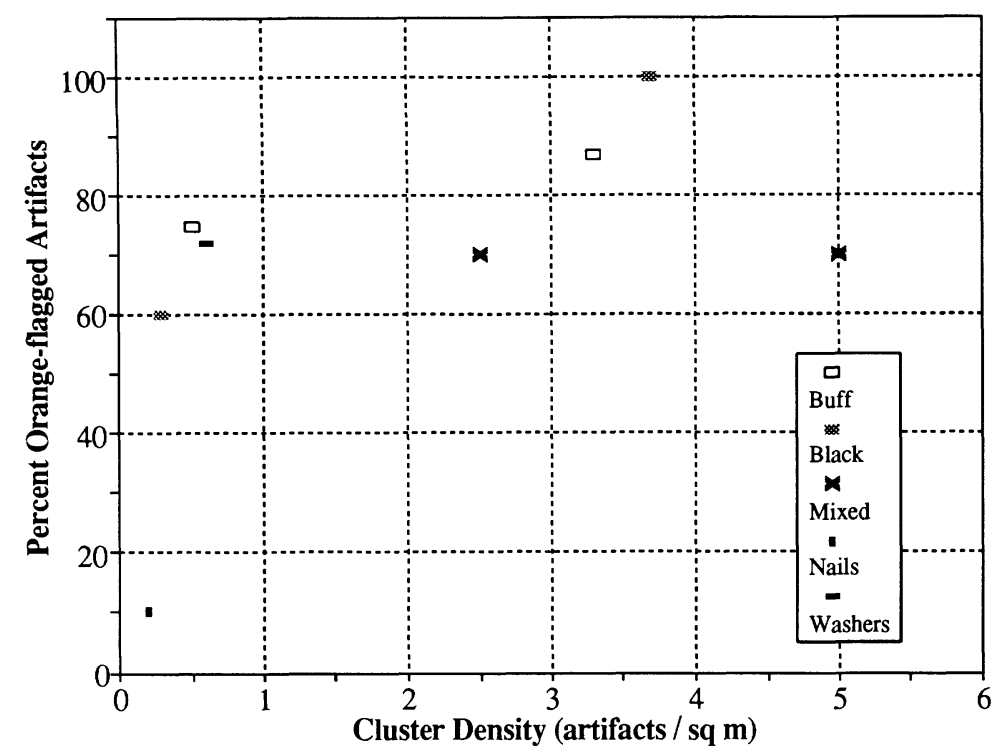

Figure 2. Seedskadee seeding experiment: percentage of orange-flagged artifacts vs. cluster density. "Buff" refers to clusters with buff washers and nails; "Black" to black washers and nails; "Mixed" to buff and black nails and washers; "Nails" to buff and black nails; and "Washers" to buff and black washers.

\section{Tonque Seeding Experiment}

The Tonque seeding experiment was conducted differently from that implemented during the Seedskadee Project. A total of 328 washers, of three diameters $(45 \mathrm{~mm}$, $26 \mathrm{~mm}$, and $19 \mathrm{~mm}$ ) and spray-painted white, brown, and black, were introduced into the unit prior to survey.

A regular, dispersed pattern of artifacts was simulated. In this case, the brown washers would have contrasted least with the surface sediments; white and black washers would have contrasted the most. Thus, this experiment focused solely on artifact obtrusiveness, as measured by artifact tone and size.

Table 2 summarizes the survey results with respect to the seeded artifacts. Between $23 \%$ and $71 \%$ of the seeded artifacts were found in each of the nine color and size classes in both discovery and encoding phases. White washers were recovered at consistently high rates, while

Table 1. Seedskadee seeding experiment results: frequency and percentage of recovered seeded artifacts by characteristics.

\begin{tabular}{|c|c|c|c|c|c|c|c|}
\hline \multirow{3}{*}{$\begin{array}{l}\text { Seeded } \\
\text { artifacts }\end{array}$} & & \multicolumn{4}{|c|}{ Recovery } & & \\
\hline & & \multicolumn{2}{|c|}{$\begin{array}{l}\text { Discovery } \\
\text { crew }\end{array}$} & \multicolumn{2}{|c|}{$\begin{array}{c}\text { Encoding } \\
\text { crew }\end{array}$} & \multicolumn{2}{|c|}{ Total } \\
\hline & & No. & $\%$ & No. & $\%$ & No. & $\%$ \\
\hline \multicolumn{8}{|l|}{$\begin{array}{l}\text { Isolated } \\
\text { Buff }\end{array}$} \\
\hline Nails & 12 & 0 & 0 & 0 & 0 & 0 & 0 \\
\hline Washers & 12 & 1 & 8 & 1 & 8 & 2 & 17 \\
\hline \multicolumn{8}{|l|}{ Black } \\
\hline Nails & 12 & 2 & 17 & 0 & 0 & 2 & 17 \\
\hline Washers & 13 & 2 & 15 & 2 & 15 & 4 & 31 \\
\hline Total & 49 & 5 & 10 & 3 & 6 & 8 & 16 \\
\hline \multicolumn{8}{|l|}{ Clustered } \\
\hline Nails & 44 & 29 & 66 & 3 & 7 & 32 & 73 \\
\hline Washers & 35 & 29 & 83 & 1 & 3 & 30 & 86 \\
\hline \multicolumn{8}{|l|}{ Black } \\
\hline Nails & 27 & 15 & 56 & 8 & 30 & 23 & 85 \\
\hline Washers & 48 & 34 & 71 & 7 & 15 & 41 & 85 \\
\hline Total & 154 & 107 & 69 & 19 & 12 & 126 & 82 \\
\hline Grand total & 203 & 112 & 55 & 22 & 11 & 134 & 66 \\
\hline
\end{tabular}


Table 2. Tonque seeding experiment results: frequency and percentage of recovered seeded artifacts by characteristics.

\begin{tabular}{|c|c|c|c|c|c|c|c|}
\hline \multirow{3}{*}{$\begin{array}{l}\text { Seeded } \\
\text { artifacts }\end{array}$} & & \multicolumn{4}{|c|}{ Recovery } & & \\
\hline & & \multicolumn{2}{|c|}{$\begin{array}{c}\text { Discovery } \\
\text { crew }\end{array}$} & \multicolumn{2}{|c|}{$\begin{array}{c}\text { Encoding } \\
\text { crew }\end{array}$} & \multicolumn{2}{|c|}{ Total } \\
\hline & & No. & $\%$ & No. & $\%$ & No. & $\%$ \\
\hline \multicolumn{8}{|l|}{ White } \\
\hline Small & 40 & 20 & 50 & 8 & 20 & 28 & 70 \\
\hline Medium & 43 & 14 & 33 & 6 & 14 & 20 & 47 \\
\hline Large & 28 & 16 & 57 & 4 & 14 & 20 & 71 \\
\hline \multicolumn{8}{|l|}{ Brown } \\
\hline Small & 43 & 3 & 7 & 7 & 16 & 10 & 23 \\
\hline Medium & 44 & 9 & 20 & 4 & 9 & 13 & 30 \\
\hline \multirow{2}{*}{\multicolumn{8}{|c|}{ Black }} \\
\hline & & & & & & & \\
\hline Small & 38 & 9 & 24 & 11 & 29 & 20 & 53 \\
\hline Medium & 43 & 6 & 14 & 10 & 23 & 16 & 37 \\
\hline Large & 23 & 7 & 30 & 8 & 35 & 15 & 65 \\
\hline Grand total & 328 & 91 & 28 & 67 & 20 & 158 & 48 \\
\hline
\end{tabular}

brown washers were recovered at the lowest rates and black washers at intermediate rates. Large washers were recorded at an expectedly high rate, while medium-sized washers were recorded at rates lower than those of the smallest, most contrastive (black and white) washers. The relatively low recovery rate of medium-sized washers may have had to do with the fact that their diameter fell within the range of that observed for the surface gravels. These medium-sized washers may have been confused with the surface gravels by the surveyors.

The generally high rate of recovery for the high contrast and large seeded artifacts in comparison with the lower recovery rate of the Seedskadee isolated seeds is interesting. This difference in rates may be owing to the high artifact density in the Tonque area relative to the Seedskadee area. In Seedskadee Unit 24 (area $=25$ ha), seeded artifacts numbered 203 and recovered prehistoric items amounted to 25 , while 328 seeds were introduced into the Tonque survey unit (area $=16 \mathrm{ha}$ ) and 2363 artifacts were recorded. In the Tonque case, it may be argued, surveyors were constantly being rewarded for their vigilance. The regular distribution of the Tonque seeded artifacts may also have contributed to the higher recovery rate. Once a surveyor had discovered one "seed," the crew became alert to finding another a measured distance away.

The Tonque experimental results reaffirm that artifact obtrusiveness is a highly situational characteristic and must be evaluated in light of local conditions. The natural "background noise" of the surface appears to determine in a large fashion the kinds of artifacts that are discovered. Both the Seedskadee and Tonque results demonstrate the utility of such studies in furthering our understanding of the documentation process.

\section{Prehistoric Artifact Discovery}

The Seedskadee and Navajo-Hopi databases consist of the detailed descriptions and locations of a large number of prehistoric artifacts. Because of the field procedures used to build these databases, it is possible to explore the effects of artifact obtrusiveness and relative density on artifact discovery. Orange-flagged artifacts from systematic survey and red-flagged artifacts from the encoding pass can be considered as two different, but not independent, samples of the same surface artifact population. While redflagged artifacts may have become exposed subsequent to the systematic survey of the unit, except for two units (Seedskadee Unit 4 and Navajo-Hopi Unit 2) little time (i.e., days) elapsed between discovery and encoding. By comparing those artifacts flagged on the first survey pass with the total documented surface artifact population (both orange- and red-flagged artifacts), some of the biases that are present in the archaeological document can be identified.

Only a portion of the Seedskadee and Navajo-Hopi databases are used in these analyses. Those artifacts that were grid-provenienced are not included. This precaution is taken because in some instances discovery crew members anticipated the gridding, which was done in cases of high artifact density, and may not have flagged as completely. Thus, a red flag in gridded areas does not necessarily mean the same thing as a red flag in a non-gridded area. Also, because of the possibility that ratios of orange to red flags may be informative about the appearance of a different analytic surface between the time of discovery and the time of artifact coding, Seedskadee Unit 4 and NavajoHopi Unit 2 are not included. 


\section{Artifact Obtrusiveness}

As discussed above, artifact obtrusiveness, frequency, and local artifact density or clusteredness may all predispose an artifact to discovery. The characteristics of an artifact that might make it more conspicuous include its size and tone (or lightness) relative to the size and tone of background surface sediments. In the Seedskadee project, size information was recorded only for chipped stone and ground stone artifacts. Length was measured in millimeters for complete flakes, all formal tools, and all ground stone. No size information for fire-altered rock was recorded and no ceramics were discovered.

The coded attributes of surface artifacts were modified and refined for the Navajo-Hopi project based on Seedskadee project experiences. For the Navajo-Hopi survey, dimensions were again recorded to the nearest millimeter for all complete flakes, formal tools, and complete ground stone artifacts. Size class $(0-30 \mathrm{~mm}, 31-60 \mathrm{~mm}, 61-$ $100 \mathrm{~mm}$, and $>100 \mathrm{~mm}$ ) was recorded for chipped stone debris, cores, and fragmentary ground stone as well as for fire-altered rock. Maximum dimension was recorded for all ceramics.

Figure 3 considers the percentage of orange-flagged artifacts of all recorded artifacts according to artifact length class for (A) Seedskadee chipped stone, and (B) Navajo-Hopi chipped stone, ground stone, and ceramics. ${ }^{2}$ In general, as artifact length increases, the artifact is more likely to have been found during the first pass and flagged in orange. Note that for the Seedskadee chipped stone two different distributions are plotted. Unit 28 was surveyed at an extremely slow pace $(500 \mathrm{~m}$ transect $/$ mean sweep time of $34 \pm 16$ minutes; or $12-28 \mathrm{~m} /$ minute); the other units were surveyed more rapidly (mean sweep $13 \pm 5$ minutes; or $28-63 \mathrm{~m} /$ minute). Of the total population of discovered artifacts, more were found during the initial systematic pass with a slower pace (Unit 28) than a faster pace (other units). Interestingly, the slopes of the two lines are very similar, which suggests that the amount of size bias contributing to artifact discovery is the same no matter the pace.

The Navajo-Hopi survey pace (400 m transect/12 \pm 2 minutes; or $28-40 \mathrm{~m} /$ minute) was intermediate to the survey rates for Seedskadee Unit 28 and the other Seedskadee units, and is attributed to the relatively higher

2. Strictly speaking, bar rather than line graphs should be used to communicate all of the trends presented here, since artifact size is a grouped variable. Our arguments about the effects of artifact obtrusiveness and clustering, however, refer to percentages of orange-flagged artifacts across size and density classes. Such comparisons are more easily seen in the degree and change in line slope than in the relative heights of bars.
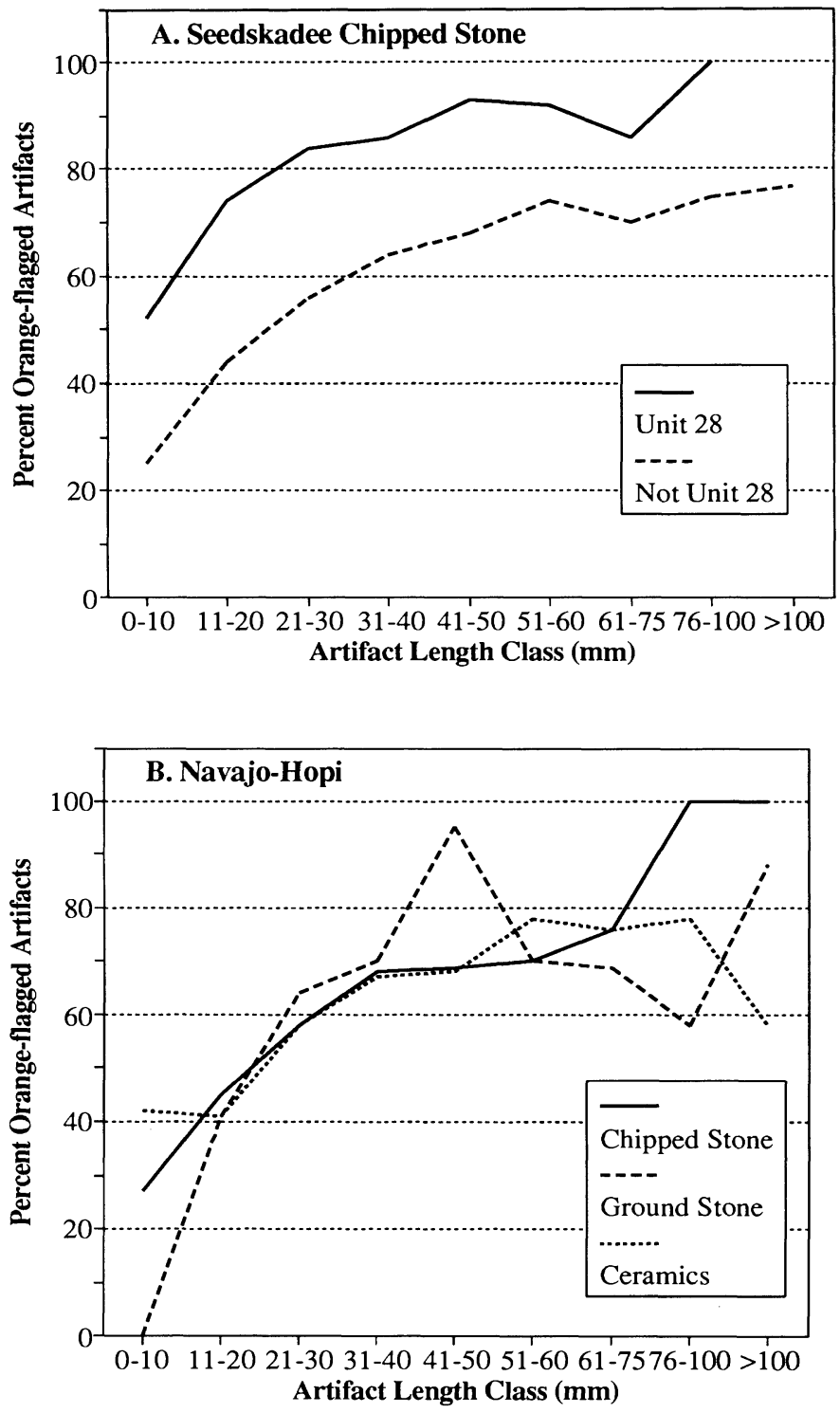

Figure 3. Percentage of orange-flagged artifacts vs. artifact length class. A) Seedskadee chipped stone. B) Navajo-Hopi artifacts.

density of artifacts found in this area. Thus, the NavajoHopi graph (FIG. 3B) most resembles that generated for the majority of the Seedskadee units, and the positive relationship between artifact size and discovery is evident. Also apparent in Figure $3 \mathrm{~B}$ are the effects of sample size. Total item frequency is very low for some classes of artifacts (i.e., ceramics with maximum dimension greater than $100 \mathrm{~mm}$, chipped stone with length greater than $76 \mathrm{~mm}$, and ground stone less than $10 \mathrm{~mm}$ and greater than $40 \mathrm{~mm}$ in maximum length). For these cases, deviations are observed from the relationship between length and discovery that is otherwise observed to be positive and remarkably similar between artifact classes. 

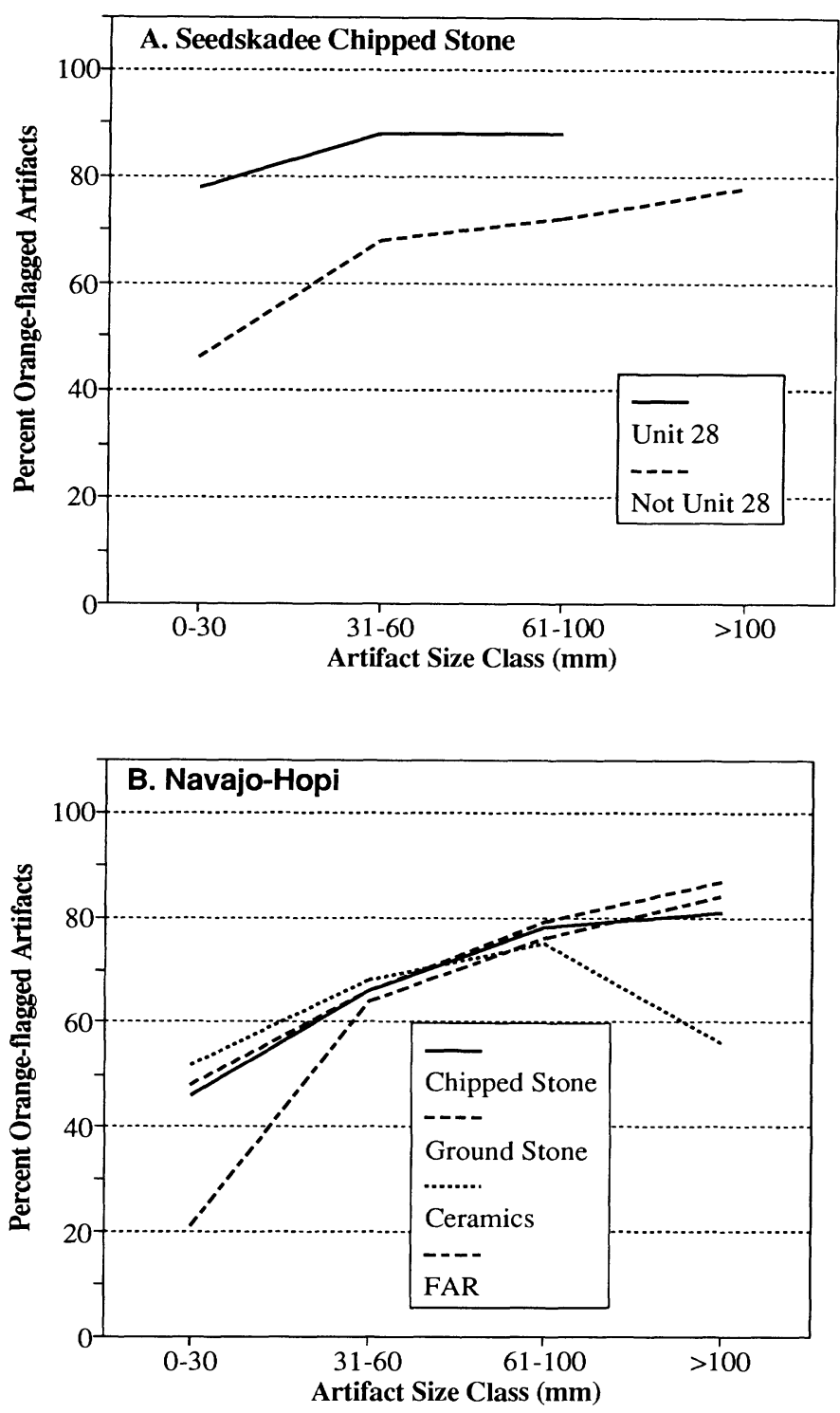

Figure 4. Percentage of orange-flagged artifacts vs. artifact size class. A) Seedskadee chipped stone. B) Navajo-Hopi artifacts.

Figure 4 presents trends similar to those depicted in Figure 3. In this figure, however, the relationships between systematic discovery results and artifact size, rather than length, classes are depicted. In addition to those artifacts for which only size class (i.e., $\mathbf{0}-\mathbf{3 0} \mathrm{mm}, \mathbf{3 1}-$ $60 \mathrm{~mm}, 61-100 \mathrm{~mm}$, and $>100 \mathrm{~mm}$ ) data were recorded, Figure 4 includes those artifacts for which recorded length has been collapsed into the appropriate size class. In Figure 4 , the resulting graphs again show that with increasing artifact size, the proportion of orange-flagged artifacts in that size class also increases. That is, the larger the artifact, the more likely it is that it will be discovered on the first survey pass.
Figure $4 \mathrm{~A}$ is a simplified version of Figure $3 \mathrm{~A}$ and is provided for comparison with Figure 4B. In Figure 4B, ground stone closely follows chipped stone, as do ceramics for those pieces smaller than $100 \mathrm{~mm}$. The frequency of sherds with maximum dimension greater than $100 \mathrm{~mm}$ is only 9 and so the low proportion of large sherds discovered with the first pass is probably attributable to the small sample size. Similarly, very small pieces of fire-altered rock, i.e., those in the $0-30 \mathrm{~mm}$ size class, number only 44 in the Navajo-Hopi assemblage, while 9659 were recorded in the small $(31-60 \mathrm{~mm})$ size class. ${ }^{3}$

Apparently similar trends in artifact discovery, as influenced by artifact size, for the Navajo-Hopi population of artifacts are remarkable in at least one respect. The different classes of artifacts manifest different clustering tendencies, yet this artifact class clustering appears not to affect artifact discovery to the same degree as does artifact size. Variance-mean ratios (see Greig-Smith 1964: 61-64; Whallon 1973) are used here to monitor degree of artifact clustering. To determine these ratios, a grid system with 25-m cells was analytically imposed on the point-provenienced population of Navajo-Hopi artifacts included in previous analyses. The mean and variance of artifact frequencies within each class of chipped stone, ceramics, etc., were calculated over all $25-\mathrm{m}$ cells. If most or all of the cells contain approximately the same number of artifacts, for a given class, then the mean and variance are about equal and the ratio of one to the other is about 1.0. If, however, some cells contain more of an artifact than other cells, i.e., the artifact is clustered, then the variance is high relative to the mean. In this case, the variance-mean ratio is greater than 1.0.

For the Navajo-Hopi data, a variance-mean ratio of 0.63 (standard error $=0.03$ ) was calculated for groundstone, indicating a regular distribution. For both chipped stone and fire-altered rock, variance-mean ratios of 2.07 (standard error $=0.02$ for both) were obtained, indicating a moderate degree of clustering for each of these. For ceramics, however, a variance-mean ratio of 4.85 (standard error $=0.04$ ) was obtained, which indicates that ceramics are clustered, at least at the $25-\mathrm{m}$ scale. In spite of these differences in degree of clustering, the artifact classes were recovered in a similar size-influenced fashion. Since clustering within the whole assemblage, not just individual artifact classes, should influence artifact discovery, these results are not surprising.

Comparing Figures $3 \mathrm{~A}$ with $3 \mathrm{~B}$, and $4 \mathrm{~A}$ with $4 \mathrm{~B}$, differences between the Seedskadee and Navajo-Hopi artifact

3. In the very small size class, only those fire-altered rocks composed of materials other than caliche were recorded. 
Table 3. Navajo-Hopi lithic materials by inferred tone. Any material that had been fired was considered "Dark."

\begin{tabular}{|ll|}
\hline Color & Rock \\
\hline Light & Quartzite \\
& Chalcedony \\
& Chalcedonic petrified wood \\
& Indeterminate sedimentary rock \\
& Sandstone \\
& Quartzitic sandstone \\
& Caliche \\
Variable & Fine-grained rhyolite \\
& Undifferentiated crystalline volcanic rock \\
& Chert \\
& Petrified wood \\
& Indeterminate cryptocrystalline rock \\
& Indeterminate metamorphics \\
& Other \\
& Indeterminate \\
& Obsidian \\
& Other glassy volcanic rock \\
Dark & Basalt \\
& Banded quartzite \\
& Coarse rhyolite \\
& Vesicular basalt \\
& Scoria \\
& Limestone \\
\hline
\end{tabular}

discovery trends are obvious. These differences may be attributable to the presence of naturally-occurring gravels in the Seedskadee area, which vie with large artifacts for the attention of the surveyor. In the Navajo-Hopi area, gravels with much smaller dimensions occur. Also, the

Figure 5. Percentage of orange-flagged artifacts vs. tone of lithic material types for Navajo-Hopi chipped stone and ground stone.

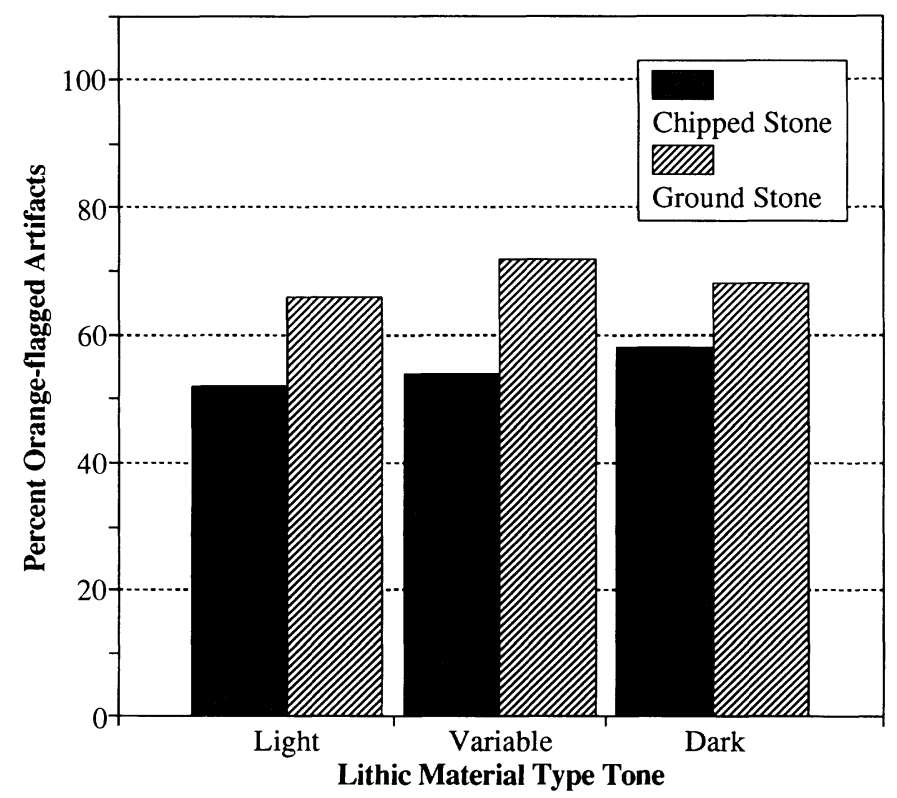

overall lower artifact density of the Seedskadee $(0.0026$ artifacts/sq m) area relative to the Navajo-Hopi $(0.0090$ artifacts/sq $\mathrm{m}$ ) area may be responsible.

In the seeding experimental results, artifact tone or coloration was found to contribute in a large measure to artifact discovery. Tone was not directly recorded in the field but can be inferred for those material types that showed little variation in color. Of all the materials considered here, only lithic materials from the Navajo-Hopi project meet this criterion. Tone classes of "light," "dark," and "variable" were constructed based on the relative coloration of the material type (see TABLE 3). Note that in this analysis, all artifacts recorded as having been firealtered are considered dark. "Variable tone" means that both dark and light coloration was observed for a particular material type. Darker artifacts might be expected to contrast more dramatically (and thus be more discoverable) than light artifacts, given the tan color of the surface sediments of the study area. Assuming that equal numbers of light and dark artifacts contribute to the category "variable tone," then this category should manifest the null hypothesis of "no trend." As depicted in Figure 5, this expected relationship is observed for chipped stone artifacts in about the same degree as observed in the Seedskadee seeding experiment. That is, $6.5 \%$ more darktoned, chipped stone was discovered during the first pass than light-toned chipped stone. No such trend, however, is seen for the ground stone.

It appears that at least some artifact classes, obtrusive artifacts, by virtue of their size and the deviation in their coloration from that of surface sediments, are more susceptible to discovery. Figure 6 elaborates on this observation. Figure $6 \mathrm{~A}$ shows that for chipped stone, when artifact color is held constant, the percentage recovered by the first survey pass increases along with artifact size. Similarly, if size is held constant at $\mathbf{0 - 3 0 ~ m m ~ o r ~ 3 1 - ~}$ $60 \mathrm{~mm}$, the percentage recovered and flagged in orange increases as material type becomes darker. Darker artifacts are found at consistently higher rates for the two smaller size classes. Larger artifacts, both dark and light, are found at similar rates. The contrast between the first-pass discovery rates of small, light-colored items and large, darkcolored artifacts is considerable. While less than $45 \%$ of the first, least obtrusive, were found during initial systematic survey, about $75 \%$ of the second, more obtrusive, were discovered. For small-sized ground stone (FIG. 6B), tone appears not to influence artifact discovery while, for larger pieces, more dark than light items were found on the first discovery pass. Note, however, that only 17 pieces of ground stone fall into this large $(>100 \mathrm{~mm})$ size class. 

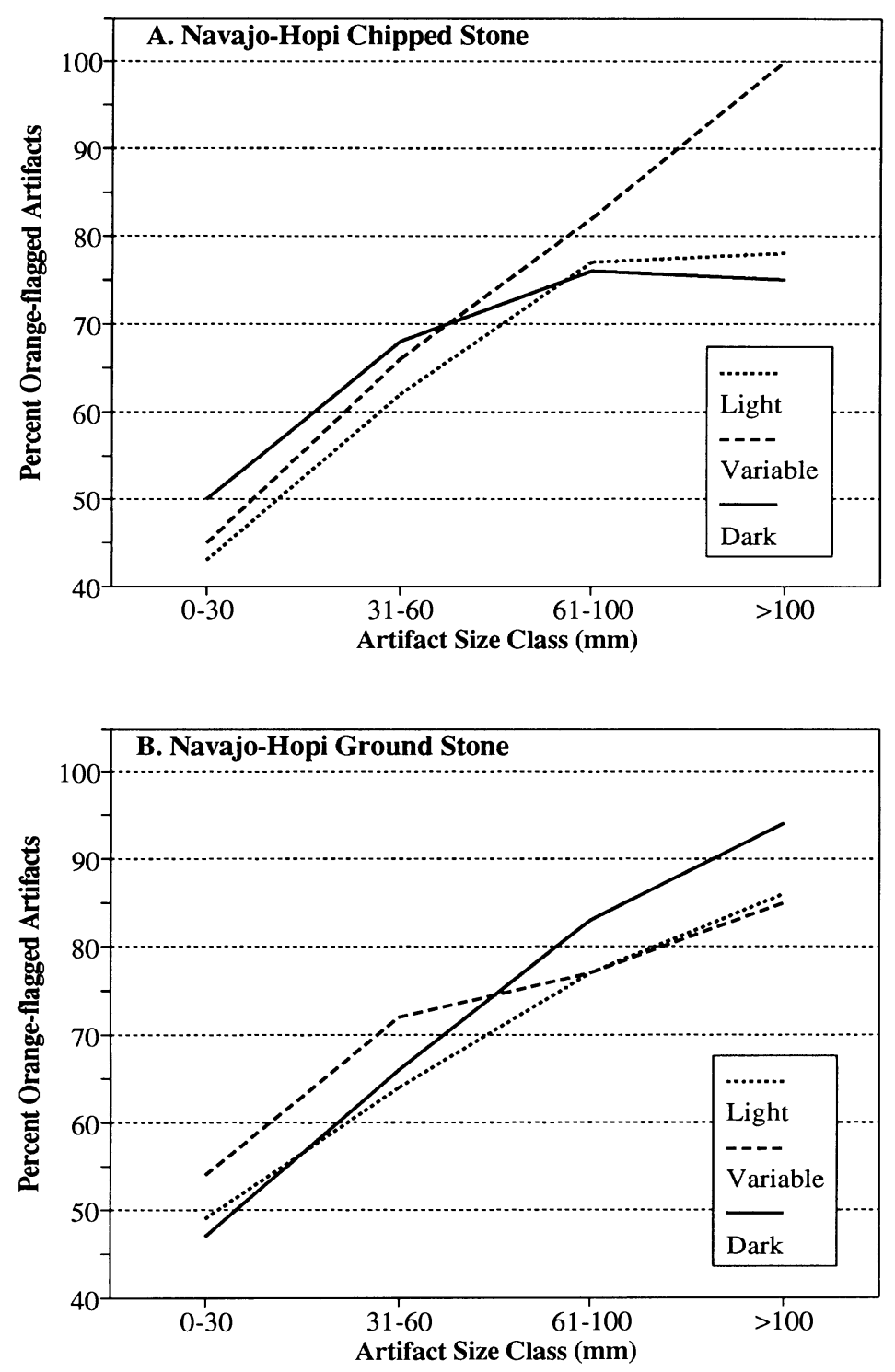

Figure 6. Percentage of orange-flagged artifacts vs. artifact size class according to Navajo-Hopi lithic material type tone. A) chipped stone. B) ground stone.

\section{Artifact Density}

In the Seedskadee seeding experiment, artifact clusteredness was found to contribute greatly to artifact discovery. This same tendency was sought in the Seedskadee and Navajo-Hopi prehistoric data by partitioning the survey units into $25 \mathrm{~m} \times 25 \mathrm{~m}$ cells and arbitrarily categorizing these cells with respect to discovered artifact density. Figure 7 summarizes artifact discovery rates according to cell density and artifact attributes of size. These data show that for higher artifact density cells, the percentage of orangeflagged items is generally low, while for lower density cells, the percentage of orange-flagged artifacts is high. That is, most of the artifacts found in high-density areas were found with the second pass, and the number of artifacts found through systematic survey may not be related to the number of artifacts actually on the surface.

Several factors are responsible for these tendencies. One is that the relationship between the numbers of orangeand red-flagged items is dependent on the amount of inadvertent resurvey by the encoding crew. Amount of resurvey, in turn, is directly related to the number of 

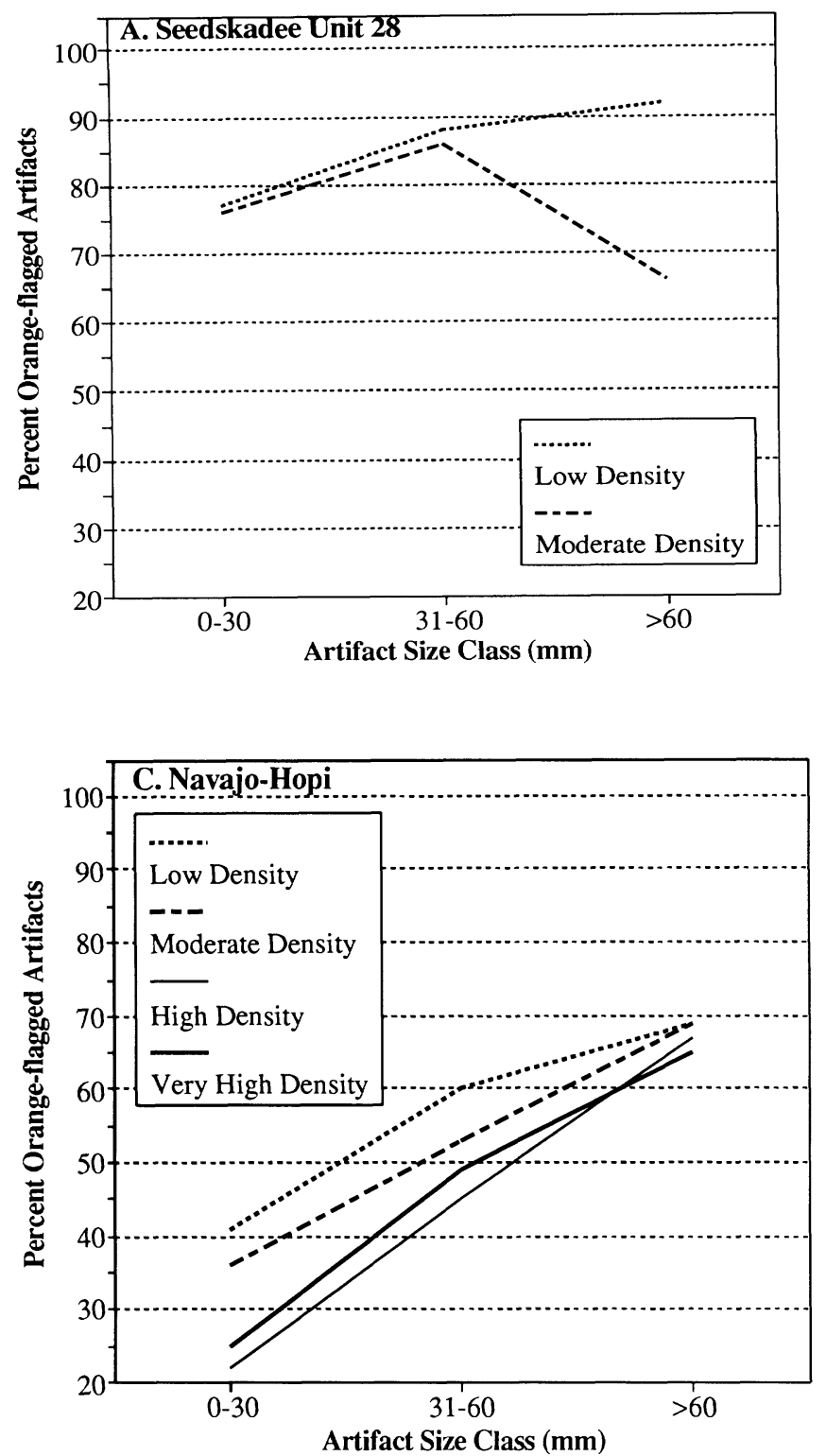

Figure 7. Percentage of orange-flagged artifacts vs. artifact size class according to artifact density (low: 1-9, moderate: 10-99, high: 100199, very high: > 200; artifacts/625 sq m). A) Seekskadee Unit 28.

B) Other Seedskadee units. C) Navajo-Hopi units.

orange-flagged items present in the unit. In general, with fewer orange-flagged artifacts, there is less resurvey by the encoding crew and fewer red-flagged artifacts. In this case, the initial discovery rate, measured by the percentage of orange flags relative to all discovered artifacts, is higher than in the case of higher density units. Thus, in the figures described below, the difference between trends graphed for low- or high-density areas is not important. Rather, the focus here is on the degree of slope of individual lines.

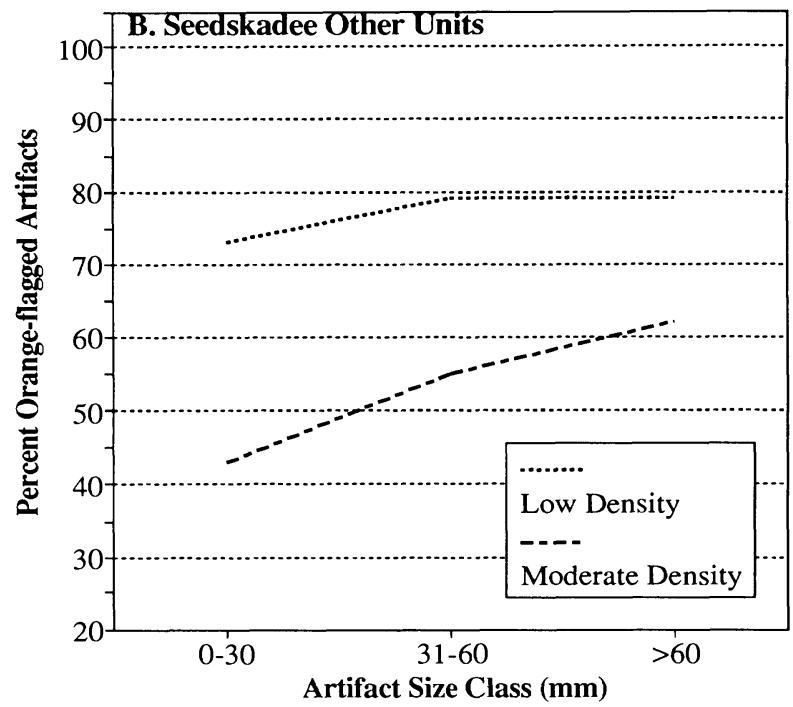

Figure 7A focuses on Seedskadee Unit 28, the one for which the initial survey was painstakingly slow. As is evident here, artifact density appears not to have influenced artifact discovery. That is, for small- and medium-sized artifacts, the percent recovered by the first pass is about the same for both low- and moderate-density areas. The number of large artifacts in each of these categories is less than 20 , however, so depicted trends for the $>60 \mathrm{~mm}$ size class are probably meaningless. A difference in percentage of orange-flagged artifacts does exist between size classes, however, and this, as discussed above, is related to artifact obtrusiveness.

For the remaining Seedskadee units (FIG. 7B), contrary to what was found in the seeding experiments, artifact size appears to make little difference with respect to artifact discovery in low-density areas. In fact, the steeper slope of the "Moderate Density" line relative to that for "Low Density" suggests that artifact size bias may be more important in the higher-density areas (but see below).

The local density-discovery relationship for NavajoHopi units (FIG. 7C) appears both similar and different from those described for the Seedskadee units. While the slopes of the size-discovery lines are quite different between the Seedskadee low- and moderate-density units, the same magnitude of difference is not observed in the Navajo-Hopi trends. Since the Seedskadee moderate-density trend is most like that observed for the Navajo-Hopi data, it is possible that the unsystematic discovery component by the Seedskadee encoding crew in low-density areas may not have been carried out with the same attention as that in other situations and hence resulted in fewer red-flagged items.

The same trend observed in the Seedskadee data, how- 
ever, that artifact size seems to be more important to artifact discovery in high- rather than low-density situations, is apparent here. That is, in the low density cells, $41 \%$ of the small and $69 \%$ of the large artifacts were discovered during the first pass, a difference of $28 \%$. For high density areas, however, $22-25 \%$ of the small and $65-67 \%$ of the large items were found during the first pass, a difference of $40-45 \%$.

Why are the trends observed in Figure 7 graphs at variance with those described for the seeding experiment? That is, why does size bias appear to be greater for the high-density record and less for the low-density record? Elsewhere (Wandsnider 1988), it has been observed for these data that the high-density record is made up in large measure by small artifacts. The following "discovery scenario" is therefore suggested. A majority of large artifacts are found with the first discovery pass, no matter what the artifact density. This statement finds support in the Navajo-Hopi data, wherein all of the lines converge in the $>60 \mathrm{~mm}$ size class at between $65-70 \%$ (FIG. 7C). As artifact size falls below $60 \mathrm{~mm}$, however, artifact discovery becomes biased, especially with respect to size. The proportion of artifacts found during the first systematic, walking pass through the area decreases with artifact size, regardless of the density. Revisiting artifacts to encode them, however, affords another opportunity to inspect the surface. Local surfaces around all initially-discovered artifacts may contain other artifacts. In some cases, smaller artifacts are recovered by this second pass and the high density record is documented. In other cases, no other artifacts, small or large, are found and a low-density record is thereby documented. Thus, the assemblage in the vicinity of initially discovered artifacts is probably accurately represented in the archaeological document for these cases. What may be under-represented, however, are instances of individual and clustered small artifacts.

These findings demonstrate that the relationship between artifact density, artifact obtrusiveness, and artifact discovery is not simple and straightforward. If artifact discovery is directly related to proportion of the surface inspected, then, from the seeding experiments, it appears that the low-density record is represented in the archaeological document in lower proportions than expected. Also, artifact obtrusiveness and the local "background noise" of the surface contribute greatly to the degree of accuracy of the archaeological document. From analysis of discovery bias in the prehistoric artifacts, it is clear that the systematic survey pass accurately finds large artifacts, no matter what their coloration or the local artifact density. It is therefore likely that in these databases, the spatial structure of the large artifacts is accurate. Smaller artifacts, however, are only found upon closer inspection of the surface, which usually occurs in the vicinity of the previously flagged artifacts. Hence, the global spatial structure of all small artifacts is probably not accurately portrayed in these databases, although its local representation is likely accurate. Thus, the size-distribution of artifacts in high-density areas is probably accurately represented by the two-pass distributional survey procedure evaluated here; such is not the case for low-density areas.

\section{Implications}

The analytic results presented here have several implications for the accuracy of survey methods. These implications are discussed here in terms of traditional site and more recent siteless survey. The first implication relates to the apparent "sitedness" of the archaeological record and is a comment on the tenacity with which field archaeologists hold to the site concept. If all clusters and only $16 \%$ of all isolated artifacts are found through high-intensity, systematic survey of an archaeological surface in the Seedskadee area, what results might a traditional site survey yield? At a transect spacing of $15 \mathrm{~m}$, many of the same artifact clusters or sites may still be found. But, since only $6-13 \%$ of the ground surface is inspected (assuming individual surveyors scrutinize the 1-2 $\mathrm{m}$ width of their transects), then only $6-13 \%$ of the artifacts falling within these transects might be found. Because of factors of obtrusiveness, however, only a portion of these might actually be discovered. Clearly, the perception that the archaeological record consists of rare "hot spots" in high artifact density and just a few dispersed artifacts is heavily reinforced by traditional discovery techniques (see also Seaman, Doleman, and Chapman 1988b: 140-143). It is therefore appropriate that these survey methods be called "site survey" and not "total coverage survey" (Cowgill 1986: 378-382, 1989: 74-76).

A corollary to this observation is that the population of "isolated occurrences" is minimally 8-17 times larger in size than that recovered through traditional moderateintensity site survey. Moreover, observations that very low-density archaeological remains appear to be comprised of large tools (Wandsnider 1988) may reflect discovery bias owing to differential artifact obtrusiveness, rather than differential use and discard.

Second, concern for the quality of the archaeological document produced through siteless survey as expressed by Doleman (1988a, 1988b) and those using distributional survey techniques (Camilli, Wandsnider, and Ebert 1988; Ebert 1992; Larralde 1990; Wandsnider 1989; Wandsnider and Larralde 1986) is not misplaced, as indicated by the results presented here. Indeed, we must 
conclude that the archaeological documents discussed here are not, at the level of artifact resolution, accurate representations of the archaeological record they reflect. Moreover, the degree of the inaccuracy varies according to surface artifact density. In areas with high artifact density, the artifact size distribution and thus the artifact assemblage is probably well-represented by the distributional, two-pass survey procedure. In low artifact density areas, however, the document is less consistent with respect to both spatial configuration and size distribution, and, to a much lesser extent, with respect to tone (and therefore material type) of artifacts.

A more general observation can be made for those siteless survey procedures that incorporate only one survey pass. In these cases, both the low- and high-density distributions are probably biased in a fashion similar to that observed for the low-density case discussed here. That is, large artifacts are probably well represented, but not the smaller artifacts, yielding a document that reflects both distorted density and assemblage composition.

Does this lack of accuracy in the survey document as produced by currently implemented distributional methods mean that high-intensity survey should not be undertaken? The arguments for high-spatial-resolution siteless and distributional survey are compelling since they are based in theory. To Dunnell and Dancey (1983), such techniques are the only means for documenting variation in the density of classes of artifacts, which reflect the differential persistence of cultural behaviors in space and time. For others interested in hunter-gatherer and early agricultural adaptations (e.g., Bettinger 1977; Button 1987; Foley 1981a, 1981b, 1981c; Irwin-Williams et al. 1988; Seaman, Doleman, and Chapman 1988a; Thomas $1971,1973,1975)$, only procedures such as these permit the detection of non-residential land use. Similarly for Bintliff and Snodgrass (1985, 1988) and Wilkinson (1989), non-residential activities such as field fertilization can only be perceived through such documentation measures. To those interested in the valid construction of land use histories (e.g., Camilli, Wandsnider, and Ebert 1988; Ebert 1992; Wandsnider 1989), only high-intensity survey procedures produce the required data. No matter the theoretical prompt, both the low- and high-density archaeological record must be documented. Continued refinement of accurate and reliable survey methods with the required degree of precision is therefore critical.

Based on results presented here, several suggestions can be made for improving the accuracy of the high-resolution survey document recorded through pedestrian survey. Further decreasing survey transect intervals and pace are obvious solutions. The effect of such measures can be anticipated by reference to the Seedskadee Unit 28 experience. That is, more of the archaeological record would be documented during the first survey pass and survey results may be less influenced by artifact density. Size bias would probably be reduced but not eliminated by such measures. For Navajo-Hopi survey results graphed in Figure $7 \mathrm{C}$, for example, all lines would terminate at around $90 \%$ rather than $65-70 \%$, be more closely grouped, and have a more shallow slope.

Evaluation of these measures and their effect on the accuracy and reliability of survey results, however, requires an independent assessment of the type afforded only by the seeding programs discussed here. Investigation of discovery bias through analysis of discovered artifact characteristics yields interesting and useful results, as testified by the above results. In the end, however, such studies are hampered by the fact that since we do not know the exact composition of the archaeological record that is being measured by the survey procedure, it is difficult to draw conclusions about survey accuracy and reliability from these data alone. We have no guarantee that the composite picture of the artifact distribution, the orange- and redflagged artifacts together, accurately represents the archaeological record. This fact points to the need for further calibration studies. Only through introduction of a control set of artifacts, in which the characteristics of the seeded assemblage are established prior to survey, can assessment of discovery bias take place. This action is not lightly recommended, for it is a costly undertaking and produces results that, owing to the immaturity of such studies, can only be generalized to a certain level. That is, the Seedskadee and Tonque seeding experiments produced redundant results to the extent that in each case the most contrastive artifacts were discovered in higher proportions as compared with less contrastive artifacts. The existence of this size-discovery relationship, of course, might be suspected even without experimentation. The configuration of this relationship is slightly different between the two cases, however, and only through survey of these "inoculated" units could this variation be recognized. At this juncture, it is not known if this difference refers to differences between the two in experimental design or in the characteristics of their individual archaeological records.

A related implication concerns how to report the quality of siteless survey results. Beck and Jones (1989: 260) suggest for artifact coding that artifact classification error be reported along with analysis results. Can a similar precision value be calculated for survey results? Should siteless survey reports contain density estimates accompanied by an error term? Operationally, such measures would have to be based on multiple surveys of the same tract of land. 
To hold the analytic surface constant, yet eliminate the possibility of surveyor memory influencing the results, multiple crews with similar levels of expertise would have to survey the same land parcel within a brief time frame. Alternatively, the same could be approached through a one-time survey of a unit containing a calibration artifact assemblage of a variety of densities.

If we were only interested in artifact density, the quality of the archaeological document could be communicated via such measures. In that questions requiring data on spatial structure at multiple scales are today more commonly asked, a measure of document quality akin to that used to describe image quality is probably more appropriate. A possible image-quality analog, for example, is the degree to which the responses of the various channels in a multispectral image either correlate, or fail to correlate, with their immediately adjacent neighbors in an expectable manner. For this reason, we have described the quality of the distributional documents in terms of representing well the assemblage and spatial structure of the higher density and large fraction of the lower density components, but poorly representing the small fraction of low-density areas. Consequent to this determination, we have tailored analysis of the artifact distributions to acknowledge these varying qualities. At present, however, we have not developed a nomenclature for efficiently reporting document quality.

\section{Conclusions}

Given the interaction between the character of the archaeological record and the survey methods discussed here and the impact of this interaction on the quality of the archaeological document, several general statements follow. First, prehistoric archaeologists are very fortunate that at least some of the materials used by the peoples they study are stable over the long term. That is, most chipped stone artifacts, unless they are deliberately destroyed, will not oxidize like metal or decay like wood. Some ceramics, such as those above a certain size (e.g., $23 \mathrm{~mm}$ is suggested by the Navajo-Hopi data) in the American Southwest, are equally impervious to destruction. This observation has implications for discovery of chipped stone and ceramics. When lithic materials are deliberately reduced through knapping and when ceramic vessels break, they break into multiple smaller, stable pieces. Human actions may leave them where they lie, may aggregate them, as in middens, or may disperse them, as in mulching or fertilizing activities (Bintliff and Snodgrass 1985, 1988; Wilkinson 1989). In the first two cases, obtrusiveness (and hence discoverability) is not dimin- ished by breakage and in fact may be enhanced. That is, numerous small artifacts may be even more obtrusive than one large artifact. That the archaeological document appears rich in these kinds of deposits should not be surprising, given the results reported here.

In the instance of dispersion or in the discard of individual small items, such as exhausted tools, cores, or retooling debris during a one-time or short-term use of a place, artifact obtrusiveness becomes important. Our discovery and documentation of materials that relate to such activities is undoubtedly seriously under-represented.

Second, with regard to archaeological survey conducted within a cultural resource management purview, the results reported here speak to at least one important issue. While it is feasible to set aside small tracts of land as archaeological preserves (Lipe 1974), it is impossible to do so with vast tracts of land upon which both low- and high-density archaeological remains may be found. Development and resource extraction concerns cannot tolerate it. In part for this reason, only small areas that have "significance" with respect to specific criteria are set aside. Typically, these small areas or archaeological sites have exposed architecture or, relative to the surrounding (and imperfectly perceived) area, high artifact densities.

Survey methods commonly used in the American West reflect this conservation sentiment. As discussed above, survey with an acceptable transect interval of $15 \mathrm{~m}$ will intercept, at most, $6-13 \%$ of the members of a low-density artifact population, but only some of these artifacts will actually be found. When found, the documentation and preservation of this record, in terms of "Isolated Finds," "Isolated Occurrences," etc., are idiosyncratic, depending on the guidelines of the land management agency and how those guidelines are interpreted by the field archaeologists. And, when documented, it is likely that this sample of the low-density record is very biased, because of differential artifact obtrusiveness. At least for the American West, we must conclude that the low-density record is not being systematically or accurately documented.

To be sure, the outcry that would be heard from the offices of land managers (not to mention field archaeologists) if they were compelled to survey their land at a $2 \mathrm{~m}$ transect interval and record all artifacts of $1 \mathrm{~cm}$ and up would be colossal. But, since the low-density record is not being found and is not being preserved, and since it contains information about how past cultural systems used the landscape that is very different from that found in documented and preserved archaeological sites, some evaluation of this record is necessary. Intensive documentation of small portions of the low-density landscape should be undertaken to determine what this record is, how to doc- 
ument it, and what biases are therefore built into traditionally-collected archaeological documents. Given the tens of millions of federal dollars spent on cultural resource management in the United States (e.g., Keel, McManamon, and Smith 1989: 25), for example, even 0.25\% of this amount spent on such ventures would be a major contribution (see Sullivan et al. 1988).

Third, the variable nature of the archaeological document suggests that archaeological analysis of survey results requires modification. Statements that rely on frequencies of different kinds of artifacts should be warranted with respect to discovery bias. That is, it would be appropriate to talk about the relative proportions of artifacts in different attribute states by context. For example, if more broken and reworked, as opposed to whole, projectile points are found in low density, as opposed to high-density, contexts, then this trend probably reflects the actual archaeological record. If, however, the opposite pattern is found, that broken projectile points occur in high-density site areas while whole projectile points are most often found away from sites, such a pattern may reflect discovery bias related to artifact size.

Finally, comprehensive calibration studies or seeding programs that consider the interactions between artifact size, tone, geometry, and clustering and the effects of this interaction on the accuracy and precision of different survey procedures are highly desirable. Such programs should also consider the different environments in which survey is conducted as the results presented here suggest. The resources required to carry out such a systematic investigation, however, are not often forthcoming within most survey projects, where emphasis is often on the size of the area surveyed and where the quality of the survey results are assumed to be "high enough." The cost of such assumptions may be admissible in some, but probably increasingly fewer, contexts. Therefore, until a library of baseline information has been compiled, all siteless surveys should incorporate a calibration component. Such studies could verify the results reported here and establish the effects of other factors (such as that survey is done with a sentient instrument capable of learning and of boredom [O'Brien et al. 1982], or may be affected by groundcover [Foley 1981c] or, atmospheric conditions [Camilli, Wandsnider, and Ebert 1988]) on document bias. Results of this and complementary surveys of control assemblages could then provide parameter estimates that would facilitate study of survey accuracy and precision through computer simulation, a less expensive alternative.

Following survey of an area, the resulting archaeological document becomes our version of the reality of the archaeological record for that area. An undiminished capac- ity for imagination ensures that archaeologists can construct equally fascinating interpretations of the past with a document that is either inaccurate and unreliable or one that faithfully represents the archaeological record. To evaluate interpretations such as these, i.e., to practice the science of archaeology, only an archaeological document that is accurate and reliable will suffice. For archaeology to make any claims about its status as a science, it must invest in apparatus, field techniques, and methods that accurately and reliably document the archaeological record. This study has endeavored to identify one of those domains where such investment is most critical.

\section{Acknowledgments}

Patrice A. Teltser, Signa L. Larralde, and George T. Jones carefully read and provided insightful comments on earlier drafts of this paper, for which we are grateful. We remain responsible for errors in fact or reasoning. The Bureau of Reclamation, the National Park Service, Las Cruces District of the Bureau of Land Management, and the National Science Foundation SBIR program supported the initial data collection that made this analysis possible. Other support was provided by the University of New Mexico Department of Anthropology, the Center for Archaeological Investigations at Southern Illinois University-Carbondale, and the Department of Archaeology, Deccan College.

LuAnn Wandsnider is assistant professor in the Department of Anthropology, University of Nebraska. Her dissertation research involved the low-density archaeological record from the American eastern Great Basin. She is interested in huntergatherer remains from arid land contexts and in research on long-term land use. Mailing address: Department of Anthropology, 126 Bessey Hall, University of Nebraska, Lincoln, NE 68588-0368.

Eileen L. Camilli is adjunct assistant professor in the Department of Anthropology, University of New Mexico. Her work focuses on interpreting the organization of past land use as reflected by regional technological and economic indicators. To this end, her research emphasizes increasing the efficiency and quality of regional archaeological field procedures. Mailing address: Department of Anthropology, University of New Mexico, Albuquerque, NM 87131.

Ammerman, Albert J.

1981 "Surveys and Archaeological Research," Annual Review of Anthropology 10: 63-88. 
Beck, Charlotte, and George T. Jones

1989 "Bias and Archaeological Classification," American Antiquity 54: 244-261.

Bernard, H. Russell

1988 Research Methods in Cultural Anthropology. Newberry Park, CA: Sage Publications.

Bettinger, Robert

1976 The Surface Archaeology of Owens Valley, Eastern California: Prehistoric Man-Land Relationships in the Great Basin. Ph.D. dissertation, University of California, Riverside. Ann Arbor: University Microfilms.

1977 "Aboriginal Human Ecology in Owens Valley: Prehistoric Change in the Great Basin," American Antiquity 42: 3-17.

Bintliff, John L., and Anthony M. Snodgrass

1985 "The Cambridge/Bradford Boeotian Expedition: The First Four Years," Journal of Field Archaeology 12: 123161.

1988 "Off-Site Pottery Distributions: A Regional and Interregional Perspective," Current Antbropology 29: 506-513.

Bowers, Peter M., Robson Bonnichsen, and David M. Hoch

1983 "Flake Dispersal Experiments: Noncultural Transformation of the Archaeological Record," American Antiquity 48: $553-572$.

Button, Van Tries

1987 The Closed Basin of Colorado's San Luis Valley: Bureau of Reclamation Archeological Investigations 1976-86. Amarillo, TX: U. S. Department of the Interior.

Camilli, Eileen, LuAnn Wandsnider, and James I. Ebert

1987 "Report on the Feasibility of a System for InstrumentAssisted Distributional Archaeological Survey," unpublished report to the NSF Small Business Innovation Research Program under Award ISI-8660765.

1988 Distributional Survey and Archeological Landscapes in the Vicinity of El Paso, Texas. Las Cruces: Bureau of Land Management, New Mexico State and Las Cruces District Offices.

Carmines, E., and R. Zeller

1979 Reliability and Validity Assessment. Sage University Papers 17. Beverly Hills: Sage Publications.

Cherry, J. F.

1983 "Frogs Round the Pond: Perspectives on Current Archaeological Survey Projects in the Mediterranean Region," in D. R. Keller and D. W. Rupp, eds., Archaeological Survey in the Mediterranean Area. BAR International Series 155. Oxford: B.A.R., 375-416.

1984 "Common Sense in Mediterranean Survey? (Reply to R. Hope-Simpson)," Journal of Field Archaeology 11: 117120.

Cowgill, George

1970 "Some Sampling and Reliability Problems in Archaeology," in J.-C. Gardin, ed., Archéologie et Calculateurs: Problèmes Sémiologiques et Mathématiques. Paris: Centre National de la Recherche Scientifique, 161-175.

1986 "Archaeological Applications of Mathematical and Formal Methods," in David J. Meltzer, Don D. Fowler, and
Jeremy A. Sabloff, eds., American Archaeology Past and Future. Washington, D.C.: Smithsonian Institution Press, 369-394.

1989 "Formal Approaches in Archaeology," in C. C. LambergKarlovsky, ed., Archaeological Thought in America. Cambridge: Cambridge University Press, 74-88.

1990 "Towards Refining Concepts of Full-Coverage Survey," in Suzanne K. Fish and Stephen A. Kowalewski, eds., The Archaeology of Regions. Washington, D.C.: Smithsonian Institution Press, 249-260.

Dancey, William S.

1973 Prehistoric Land Use and Settlement Patterns in the Priest Rapids Area, Washington. Ph.D. dissertation, University of Washington, Seattle. Ann Arbor: University Microfilms.

Davis, E. L.

1975 "The 'Exposed Archaeology' of China Lake, California," American Antiquity 40: 39-53.

Davis, M. B.

1967 "Pollen Deposition in Lakes as Measured by Sediment Traps," Geological Society of America Bulletin 78: 849858.

1976 "Erosion Rates and Land-Use History in Southern Michigan," Environmental Conservation 3: 139-148.

Doleman, William H.

1988a "Calibration of Phase I Data: Problems in Sampling Archaeological Landscapes," in Timothy J. Seaman, William H. Doleman, and Richard C. Chapman, eds., The Border Star 85 Survey: Toward an Archeology of Landscapes. Albuquerque: Office of Contract Archeology, University of New Mexico, 31-62.

1988 b "Calibration of Phase I Data: Effective Resolution," in Timothy J. Seaman, William H. Doleman, and Richard C. Chapman, eds., The Border Star 85 Survey: Toward an Archeology of Landscapes. Albuquerque: Office of Contract Archeology, University of New Mexico, 63-84.

Drager, Dwight, and Arthur K. Ireland, eds.

1986 The Seedskadee Project: Remote Sensing in Non-Site Archeology. Washington, D.C.: U. S. Department of the Interior.

Dunnell, Robert C., and William S. Dancey

1983 "The Siteless Survey: A Regional Scale Data Collection Strategy," in Michael B. Schiffer, ed., Advances in Archaeological Method and Theory 6: 267-287.

Ebert, James I.

1992 Distributional Archaeology. Albuquerque: University of New Mexico Press.

Ebert, James I., Signa Larralde, and LuAnn Wandsnider

1987 "Distributional Archaeology: Survey, Mapping, and Analysis of Surface Archaeological Materials in the Green River Basin, Wyoming," in Alan J. Osborn and Robert C. Haskell, eds., Perspectives on Archaeological Resources Management in the Great Plains. Omaha: I and O Publishing, 159-178. 
Fish, Suzanne K., and Stephen A. Kowalewski, eds.

1990 The Archaeology of Regions. Washington, D.C.: Smithsonian Institution Press.

Foley, Robert

1981a "A Model of Regional Archaeological Structure," Proceedings of the Prehistoric Society 47: 1-17.

1981b "Off-site Archaeology: An Alternative Approach for the Short-Sited," in I. Hodder, G. Isaac, and N. Hammond, eds., Patterns of the Past: Studies in Honor of David Clarke. Cambridge: Cambridge University Press, 157-183.

1981c Off-site Archaeology and Human Adaptation in Eastern Africa: Analysis of Regional Artifact Density in the Amboseli, Southern Kenya. Cambridge Monographs in African Archaeology 3. BAR International Series 97. Oxford: B.A.R.

Gallant, T. W.

1986 "Background Noise' and Site Definition: A Contribution to Survey Methodology," Journal of Field Archaeology 13: $403-418$.

Grieg-Smith, Peter

1964 Quantitative Plant Ecology, 2nd ed. London: Butterworths.

Hope-Simpson, Richard

1983 "The Limitations of Surface Surveys," in D. R. Keller and D. W. Rupp, eds., Archaeological Survey in the Mediterranean Area. BAR International Series 155. Oxford: B.A.R., $45-48$.

1984 "The Analysis of Data from Surface Surveys," Journal of Field Archaeology 11: 115-117.

Irwin-Williams, Cynthia, Christopher Pierce, Stephen R. Durand, and Patricia Hicks

1988 "The Density Dependent Method: Measuring the Archeological Record in the Northern Southwest," in LuAnn Wandsnider and James I. Ebert, eds., Issues in Archeological Surface Survey: Meshing Method and Theory. American Archeology 7: 38-54. Albuquerque, NM: Atechiston Press, Inc.

Judge, W. James

1981 "Transect Sampling in Chaco Canyon-Evaluation of a Survey Technique," in Alden C. Hayes, David M. Brugge, and W. James Judge, eds., Archaeological Surveys of Chaco Canyon, New Mexico. Washington D.C.: U. S. Department of the Interior, 107-137.

Keel, Bennie C., Francis P. McManamon, and George S. Smith, compilers

1989 Federal Archaeology: The Current Program. Washington, D.C.: U. S. Department of the Interior.

Larralde, Signa L.

1990 The Design of Hunting Weapons: Archaeological Evidence from Southwestern Wyoming. Ph.D. dissertation, University of New Mexico, Albuquerque. Ann Arbor: University Microfilms.

Lewarch, Dennis E., and Michael J. O'Brien

1981 "The Expanding Role of Surface Assemblages in Archaeological Research," in Michael B. Schiffer, ed., Advances in Archaeological Method and Theory 4: 297-342.
Lipe, William D.

1974 "A Conservation Model for American Archaeology," The Kiva 39: 215-245.

Mueller, James W., ed.

1975 Sampling in Archaeology. Tucson: University of Arizona Press.

Nance, Jack D.

1981 "Statistical Fact and Archaeological Faith: Two Models in Small-sites Sampling," Journal of Field Archaeology 8: 15l-165.

1988 "Reliability, Validity, and Quantitative Methods in Archaeology," in Mark S. Aldenderfer, ed., Quantitative Research in Archaeology. Newbury Park: Sage Publications, 244-293.

O'Brien, Michael J., Roger D. Mason, Dennis E. Lewarch, and James A. Neely

1982 A Late Formative Irrigation Settlement Below Monte Albán: Survey and Excavation on the Xoxocotlan Piedmont, Oaxaca, Mexico. Austin: Institute of Latin American Studies, University of Texas Press.

Plog, Stephen

1976 "Relative Efficiencies of Sampling Techniques for Archaeological Surveys," in Kent V. Flannery, ed., The Early Mesoamerican Village. New York: Academic Press, 136158

1986 "The Survey Strategy," in Stephen Plog, ed., Spatial Organization and Exchange-Archaeological Survey on Northern Black Mesa. Carbondale: Southern Illinois University Press, 33-49.

Plog, S. F., F. Plog, and W. W. Wait

1978 "Decision Making in Modern Surveys," in Michael B. Schiffer, ed., Advances in Archaeological Method and Theory 1 : $383-421$.

Powell, Shirley, Lisa Leat, and Rick Thomas

in press "Archaeological Survey Data: How Consistently Do Archaeologists Record Them?" American Antiquity.

Read, Dwight W.

1986 "Sampling Procedures for Regional Surveys: A Problem of Representativeness and Effectiveness," Journal of Field Archaeology 13: 477-491.

Raab, L. Mark

1979 "The Impact of Contract Archaeology on Analysis of Surface Data: Prospects and Problems," in M. J. O'Brien and D. E. Lewarch, eds., Recent Approaches to Surface Data and Sampling. Western Canadian Journal of Anthropology 8: 106-113.

Schiffer, Michael B., and Susan J. Wells

1982 "Archaeological Surveys: Past and Future" in R. H. McGuire and Michael B. Schiffer, eds., Hohokam and Patayan: Prehistory of Southwestern Arizona. New York: Academic Press, 345-383.

Schiffer, Michael B., Alan P. Sullivan, and Timothy C. Klinger 1978 "The Design of Archaeological Surveys," World Archaeology 10: 1-28.

Seaman, Timothy J., William H. Doleman, and Richard C. Chapman, eds.

1988a The Border Star 85 Survey: Toward an Archeology of Land- 
scapes. Albuquerque: Office of Contract Archeology, University of New Mexico.

Seaman, Timothy J., William H. Doleman, and Richard C. Chapman

1988b "Summary and Conclusions," in Timothy J. Seaman, William H. Doleman, and Richard C. Chapman, eds., The Border Star 85 Survey: Toward an Archeology of Landscapes. Albuquerque: Office of Contract Archeology, University of New Mexico, 137-144.

Sullivan, Alan P., III, Mark A. Calamia, Bruce R. Donaldson, Paul R. Fish, Emily Garber, John A. Hanson, Susanna R. Katz, Carl J. Phagan, and LuAnn Wandsnider

1988 "Landscape Archaeological Research and Cultural Resources Management," in Joseph A. Tainter and R. H. Hamre, eds., Tools to Manage the Past: Research Priorities for Cultural Resources Management in the Southwest. USDA Forest Service General Technical Report RM-164. Fort Collins, 98-108.

Thomas, David H.

1971 Prehistoric Subsistence-Settlement Patterns of the Reese River Valley, Central Nevada. Ph.D. dissertation, University of California, Davis. Ann Arbor: University Microfilms.

1973 "An Empirical Test of Steward's Model of Great Basin Settlement Patterns," American Antiquity 38: 155-176.

1975 "Nonsite Sampling in Archaeology: Up the Creek without a Site?" in James W. Mueller, ed., Sampling in Archaeology. Tucson: University of Arizona Press, 61-81.

Wandsnider, LuAnn

1988 'Cultural Resources 'Catch-22' and Empirical Justification for Discovering and Documenting Low-Density Archeological Surfaces," in Joseph A. Tainter and R. H. Hamre, eds., Tools to Manage the Past: Research Priorities for Cultural Resources Management in the Southwest. USDA Forest Service General Technical Report RM-164. Fort Collins, 90-97.

1989 Long-term Land Use, Formation Processes, and the Structure of the Archaeological Landscape: A Case Study from Southwestern Wyoming. Ph.D. dissertation, University of New Mexico, Albuquerque. Ann Arbor: University Microfilms.

Wandsnider, LuAnn, and James I. Ebert

1984 "Accuracy in Archaeological Surface Survey in the Seedskadee Project Area, Southwestern Wyoming," Haliksa'i: UNM Contributions to Anthropology 3: 9-21.

Wandsnider, LuAnn, and Signa Larralde

1986 "Seedskadee Cultural Resources Assessment Project: Report to the Branch of Remote Sensing, National Park Service," in Dwight L. Drager and Arthur K. Ireland, eds., The Seedskadee Project: Remote Sensing in Non-Site Archeology. Washington, D.C.: U. S. Department of the Interior, 151-210.

Whallon, Robert, Jr.

1973 "Spatial Analysis of Occupation Floors I: Application of Dimensional Analysis of Variance," American Antiquity 38: $320-328$.

Wilkinson, T. J.

1989 "Extensive Sherd Scatter and Land-Use Intensity: Some Recent Results," Journal of Field Archaeology 16: 31-46.
Zeller, Richard A., and Edward G. Carmines 1980 Measurement in the Social Sciences. London: Cambridge University Press. 